had by application to Sir John Lawes at Rothamsted Park, St. Albans.

The task of reviewing matter of so condensed a character as this is by no means easy. Ever since I840, Sir John Lawes has carried out field and stall experiments on a scale well worthy of a national enterprise. Elaborate papers by this most enterprising of experimentalists, and his equally well-known coadjutor, Dr. T. H. Gilbert, have poured forth from Rothamsted during the entire memory of the present gencration. During the last twenty-five years the scientific staff presided over by Dr. Gilbert has consisted of two, and sometimes three, chemists, and as many competent assistants, a botanical assistant, two to four computors and record-keepers, besides laboratory men. From I 847 to 1884 ninety-six memoirs have been contributed upon subjects bearing upon the soil, the plant, the atmosphere, drainage water, and rainfall, utilisation of sewage, animal nutrition, feeding-materials, manures, the occurrence of fairy rings in pastures, \&c., \&c. There is, in fact, scarcely a topic of agricultural or pastoral life which has not been investigated at this great English Agricultural station, and that through the enterprise of one man.

The Memoranda commence with a summary of rainfall and drainage extending backwards to $185 \mathrm{I}$. Not only is the local rainfall given for each month over a period of nineteen years, but also the amount percolated through gauges of 20,40 , and 60 inches in depth of soil, the amount evaporated, and the amount retained by capillary attraction in the soil. Thus, as a general summary of the total rainfall, we find $45^{\circ} 3$ per cent. percolated through 20 inches depth of soil, $47^{\circ} 4$ per cent. through 40 inches of soil, $4^{\circ} 9$ per cent. through 60 inches of soil, as indicated by rain- or drain-gauge, while the remainder is accounted for by evaporation or retention in the interstices of the soil. The averages obtained by unremitting observation from $185 \mathrm{I}$ to 1870 are used in comparison with subsequent years, as in the case of the last completed record from September, I 882, to August, I 883. The three last columns of the tables given are devoted to the nitrogen removed in solution by percolation of drainage-water calculated in pounds per acre, by which we see that, at the depths above-mentioned, from 36 to $44 \mathrm{lbs}$. of nitrogen per acre are annually carried down from the upper layers of the soil to a depth of 5 feet and more.

One of the most attractive series of experiments, extending now over a period of thirty years, is that carried. out upon permanent grass-land in the Park at Rothamsted. Space forbids morc than a most cursory sketch of these experiments. Like all the Rothamsted investigations, the first aim is practical and comparative. The questions asked are as follows:- What is the effect of various applications to grass land? Which gives the largest return? What is the effect upon the herbage of continuous and of varied treatment? What is the effect upon the soil of long-continued privation and of longcontinued feeding with simple and combined dressings? The investigation is at once chemical, physical, and botanical, and the change wrought in the character of the herbage of various contiguous plots of natural pasture, as well as upon the soil to a great depth, is most remarkable.

Perhaps the chief interest in the experiments upon crop cultivation will still centre around wheat. Broadbalk field, on the Rothamsted estate, is unique, so far as treatment and cropping goes. In I 839 this field carried a crop of turnips, manured with farm-yard dung; in 1840 it was barley; in I841, peas; in 1842, wheat; in 1843 , oats : all the four last crops being unmanured. The field was, therefore, according to all farming rules, in an exhausted state when the first experimental crop of wheat occupied it in 1844 . Every year since 1843 has this field carried wheat, and, with some exceptions, nearly the same description of manure has been applied to each plot. In this field the visitor, during the present summer, will see the forty-second wheat-crop growing without manure of any description upon the unmanured portion of the field, still keeping up a wonderfully uniform yield of about thirteen bushels per acre-or about the average yield of wheat-Iands in the United States of America. This is a striking fact for those who fear the eventual exhaustion of our soils. Equally startling is the result from the continued use of nitrate of soda year after year. This fertiliser is looked upon by many landlords and agents with suspicion as a stimulator and exhauster of the soil ; and yet after forty-one years application of nitrate of soda, and nothing else, we have the astounding result of an average of $23 \frac{1}{2}$ bushels per acre, or double the yield of the unmanured plot. And, although it is true that the yield of the unmanured and nitrate of soda plots is less upon an average from 1868 to 1883 than it was from I852 to 1867, yet it is equally true of the plot manured with I4 tons of farmyard manure annually; and this falling off is therefore probably due to a succession of bad seasons, more than to any actual exhaustion of the soil. Another striking fact brought out in these experiments is the excellent results achieved by applications of artificial fertilisers as contrasted with those obtained from farm-yard manure. In the latter case, where I 4 tons of dung have been annually applied to the wheatplot for forty years in succession, the very satisfactory yield of $33 \frac{1}{2}$ bushels per acre has been obtained over the entire period. When, however, a well-compounded mixture of artificial fertilisers has been applied, a larger yield has been obtained. For example, $200 \mathrm{lbs}$. of sulphate of potash, Ioo lbs. of sulphate of soda, Ioo lbs. of sulphate of magnesia, $3 \frac{1}{2} \mathrm{cwts}$. of superphosphate, and $600 \mathrm{lbs}$. of ammonia salts, have given upon an average over the same long period 36 bushels per acre year by year. We must not draw these remarks to a conclusion without at least noting the interesting experiments upon barley, the leguminous crops, clover sickness, root crops, and potatoes. The memoranda close with a synopsis of a series of experiments upon rotations of crops commenced in 1848 in order to test the effect of growing crops in rotation, instead of continuously, and so to arrive at precise results when a system of mixed farming is pursued with and without manures, and in conjunction with sheep farming.

JOHN WRIGHTSON

\section{RECENT EXPLORATIONS OF THE PAMIR}

THE third fasciculus of the Izvestia of the Russian Geographical Society contains three very interesting papers, by D. L. Ivanoff, on the Pamir, being the results of the expedition of MM. Ivanoff, Putyata, and Bendersky, already mentioned in NATURE. The first of these papers deals with the journeys of the members of the expedition; the second contains the author's views on the orography of the Pamir ; and the third gives a description of the flora, fauna, and inhabitants of this "Roof of the World." Leaving aside the purely geographical part (M. Ivanoff's papers should be translated into English), I shall sum up the most important orographical results arrived at by the author, as also his observations on the natural history of the Pamir.

As to its limits, so variously determined by geographers, M. Ivanoff places them-rightly in my opinion-as follows:-The Alay Mountains in the north, the Hindukush in the south, and the Kashgar Mountains in the east. As to its western limits, the following remarks ought to be made:- The whole of the highlands on the upper Amu-daria must be divided into two parts-the Eastern Pamir and the Western. The Eastern Pamir is a very high plateau, intersected by numerous valleys, rivers, and lakes, with an average height above the sea-level of 12,000 feet (from I0,000 to I4,000). These valleys are either separated by chains of mountains 
or by low swellings which mostly reach only from I 100 to I 500 feet above the level of the surrounding valleys, and very seldom 3000 feet. The slope of these swellings above the valleys is so gentle that water-sheds only 1 Ioo to I 500 feet high are often twenty to fifty miles distant from their foot. These high valleys strictly correspond to what the inhabitants call "Pamir." "Pamir" signifies, in fact, "a flat roof," and when the inhabitants want to describe it in more detail, they add: "broad valleys between low mountains, so high, however, that nothing but grass may grow on them ; where there is nothing," they say, "and the earth is like the palm of the hand, that is the Pamir." So they describe what a geographer would call a High Plateau. This plateau has, on the whole, the shape of a great horse-shoe, in the middle of which are situated the mountains of the Murghab and Alichur. This does not imply, however, that there are absolutely no mountain-ridges on the plateau; no angehaufte Gebirge, as Karl Ritter would say. The Pamir chain of mountains which runs east-north-east between the Pamir and the Alichur rivers in the south belongs to this category. It rises above the Great Lake as a stone wall 3500 to 5000 feet high; but it has its foot in the 10,000-feet-high valleys which surround the lake, and belongs to the category of the angehaufte Gebirge. Several other lower chains, such as the Alay, Trans-Alay, Kiang-kul, Murghab, Alichur, and Vakhan, run in the same direction over the surface of the great plateau, and have the same character.

As to the Western Pamir, which might be described as the mountainous Pamir, it has quite another character. The whole of the plateau sinks towards the west, but, at the same time, numerous chains of mountains make their appearance. We have there, according to Ritter's classification, an Alpine country. The rivers, which flow lazily in the east, become rapid, their valleys narrow; crags, rocks, and hills confine them; the routes become difficult, and the mountain-passes very rare. The rich prairies of the east disappear also; giving place to forests, and, lower down, to agriculture, which rises as high as 8000 feet in the north and Io,ooo feet in the south. Even the inhabited valleys are mere mountain-gorges. It is obvious that, under such conditions, the real western limits of the Pamir cannot be determined with exactitude; and we consider M. Ivanoff very near the truth when he says that the Western Pamir merges into the Alpine highlands of the Darwaz, Shugnan, and Badakshan. The limits are thus far more undefined in the west than in the north and east. The author considers, thus, that the Shugnan and Darwaz ought not to be included in the Pamir proper; they might be considered rather as a highland which has risen at theintersection of the eastern with the north-western ones of the Hindu-kush (as border ridges?). The Pamir would thus appear as a mighty plateau about 170 miles long, 200 miles wide in the meridional direction, and covering nearly 34,000 square miles.

As to the much-spoken-of meridional upheaval of the Bolor, M. Ivanoff points out that there are absolutely no traces of upheavals having a direction either from north to south, or even towards north-north-west or northnorth-east. On the contrary, all his observations on the stratification of rocks-and they are numerous-show that the stratification follows the direction either of eastnorth-east (that of the whole Central Asian plateaux), or north-west, that is, that of the Hindu-kush. The same is true with regard to longitudinal valleys, which always follow a direction towards north-north-east. As to the Kashgar Mountains, still unexplored, they seem to repre. sent a repetition of shorter chains running towards northwest, and arranged in échelon.

If this opinion of $M$. Ivanoff is confirmed-and it most probably will be, as it pretty well corresponds with the broad lines of the structure of the Central Asian plateaux, as also with what is already known as to their structure-we shall have definitely to renounce seeking for meridional chains in this part of Asia. We have already been brought to renounce them in North-Eastern Asia, where I believe I have proved that neither the Great Khingan nor the Kuznetzki Alatau, nor even the Sikhota-alin, have this direction. On the contrary, we will perceive that the Pamir is only the highest terrace of a series of plateaux extending throughout the central parts of Asia in a north-eastern direction from the source of the Amu to Behring Strait.

But let us return to M. Ivanoff's papers, and to his observations on the flora and fauna of the Pamir. The high valley of the Alay already belongs to the Roof of the World. It is covered with rich prairies, the chief elements of which are Gramineæ. Nearer to water you find a thick growth of Carex physodes, which has given its name, Riang, to so many parts of the Pamir highlands. Numerous species of Papilionacex, many of them relations of the flowers of our European meadows, give a pleasant aspect to the steppes of the Alay in June. The same character-a mixture of the vegetation of the steppes with that of cold climates and highlands-is found also on the Eastern Pamir as you advance further south. But it is sufficient to descend into the valleys of the west to find immediately a far richer flora and, very soon, corn-fields.

The animals inhabiting the Pamir are also a mixture of those of the steppes with those of Alpine regions. The tame yak (Bos indicus) is met with the well-known "arkhars." Although their horns are scattered in great numbers on the Pamir, they are far from disappearing, and M. Ivanoff has seen numerous herds of from $I 00$ to 150 , and considers that they ought to be counted by thousands in the neighbourhood of the Great Lake. In the mountains the "kiiks" (Capra, probably sibirica) are numerous, but very difficult to approach; the brown bear is common, and M. Ivanoff's men killed four of them. The wolf of the steppes unavoidably accompanies the herds of arkhars. The yellow marmots (Arvicola caudatus) are very numerous; the steppes of the Pamir are their true dwelling-places, and the expedition has met also with great numbers of small Siberian hare, which is common on the Issyk-kul. The Indian goose, the Syrrhaptes of the high steppes, the Megaloperdix tibetana in the rocky hills, and the Perdix chukar-this last met with only once at a height of 14,000 feet-are especially worthy of notice.

As to the climate of Pamir, it is, of course, very severe. The winter reigns in full for seven months. As to frosts, there is hardly one single month without them, and even on July and August nights the expedition experienced frosts of $6^{\circ}$ below zero. There are places on the Pamir where snow rarely reaches a great depth, but, its distribution depending mostly upon the prevailing winds, there are places where it falls in thick layers. As to the rivers, even the Murghab freezes for some time.

The true inhabitants of the Pamir are the Kirghizes, namely, the Kara Kirghizes, who belong to four different stems-Teit, Gadyrsha, Nayman, and Kiptchak. The chief settlements are situated in the valleys of the Northern and Southern Ghezia, about the Riang-kul, on the Ak-baital, the Ak-su, the Alichur, and in the basin of the Kokui-bela. They are found also on the Upper Tagarma. These Kirghizes are very much like those of the Alay, but a special feature of them-very rare, on the whole, with the Mongolian race-is that they continually suffer from tooth-ache; perhaps it depends upon the climate; at any rate, common disease-an inflammation of the eyes-obviously depends upon the clouds of salt dust raised on the Pamir by the western winds. They spend the winter, at a height of II,000 to 12,000 feet, in the same tattered kibitkas, that they inhabit in the summer, and know nothing of the warm dwellings erected for the winter by the Alay Kirghizes. 
In the summer they ascend to the hilly tracts, reaching about 14,000 feet, in order to save their cattle from the mosquitoes. Though living chiefly on milk produce, they still are dependent upon the inhabited countries of the west, for they are accustomed to the use of bread. The other race inhabiting, if not the Pamir itself, then its outskirts, are the Tadjiks. In the high valleys of the Shugnan, the Roshan, the Darwaz, and the Karategin, they occupy the narrowest gorges of the mountains, trying to escape there from the persecutions of their khans, who are themselves vassals to the neighbouring larger states like Bokhara, Kokan, or China. Being Shiites, they are still more persecuted by their Sunnite rulers. Their dwellings are miserable hovels built of rough stones. Broad wooden platforms, under which fowls and young goats are kept, are divided into numerous compartments, which might be called rooms, each of them having its special destination as a kitchen or as a room for weaving, and so on. Notwithstanding the surrounding poverty, one feels comfortable in their poor hovels, the walls of which are decorated with numerous clay pillars, niches, and a variety of paintings very artistically made by the women, who have found the means of fabricating even boxes from clay mixed with husk. The pottery, all made by women without instrumental aid, is striking in the artistic feeling infused into its fabrication. Their fields are not less striking by the incredible labour which has been spent in clearing them from millions of stones. There are "fields" not larger than a common-sized table, cleared with effort, or artificially made by the side of a mountain stream. They keep some cattle, and, during the summer, mount with it to higher tracts. The Pamir is visited by many savdagars, or traders, from Kashgar, Badakshan, or Ferghana, who supply the Kirghizes and Tadjiks, at very high prices, with manufactured produce, receiving in exchange their own produce.

M. Ivanoff remarks that the small preliminary map published in the Izvestia, to illustrate the explorations of his expedition, is still incomplete, and does not quite correctly represent the results of his investigations. The larger completed map will therefore be welcomed when it appears.

P. $\mathrm{K}$.

\section{NOTES}

A meEting of the General Committee of the Darwin Memorial Fund was held last week at the rooms of the Royal Society, Prof. Huxley, President, in the chair, when it was stated by the treasurer, Dr. Evans, that, after payment for the statue and other expenses, a balance of about 2200l. would remain. The following resolutions were then passed:-- "That the statue of Darwin be made over to the Trustees of the British Museum in trust for the nation." "That the balance of the fund, after payment for the statue and medallion and incidental expenses, be transferred, under the name of the 'Darwin Fund,' to the President, Council, and Fellows of the Royal Society in trust to invest the same in or upon any stocks, funds, or securities authorised by law as investments for trust moneys." "That the President and Council of the Royal Society apply from time to time the dividends and interest of such investments in such a manner as shall to them appear best calculated to promote biological studies and research." "That a list of subscribers and a statement of the accounts be printed and circulated, together with the resolutions now passed, and that a woodcut or some other representation of the statue accompany the statement." The statue, by Mr. Boehm, R.A., has been placed in the great hall of the British Museum (Natural History), Cromwell Road, and arrangements for its unveiling will be made shortly.

THE vacancy created by Prof. Bayley Balfour's retirement from the Regius Chair of Botany in the University of Glasgow, which we announced some time back (NATURE, March 12, p. 44I), has been filled by the appointment of Mr. F. O. Bower, F.L.S., Lecturer on Botany in the Normal School of Science, South Kensington. Both as a teacher and by his important researches in the morphology of Gymnosperms and the Vascular Cryptogams, Mr. Bower has rapidly assumed a leading position amongst the younger generation of botanists, and the loss of his services to the Normal School is much to be regretted. Mr. Bower is an M.A. of Trinity College, Cambridge.

THE Goldsmiths' Company has contributed one hundred pounds towards the fund which is being raised for the family of the late Henry Watts, to which we have already drawn attention in these columns.

ThE Court of Assistants of the Fishmongers' Company has unanimously resolved that a grant of $2000 \%$. be made to the Marine Biological Association of the United Kingdom-1000/. to be paid this year, and the remainder in annual sums of $200 \%$. during the next five years.

THE subject of Mr. Romanes's Rede Lecture on June 2 wil be "Mind and Motion."

THE subject of Prof. W. G. Adams's British Association address will be "The Electric Light and Atmospheric Absorption."

AT a meeting of the directors of the Ben Nevis Observatory held on Thursday last week, it was agreed to add a printing press to the establishment, for printing each day the hourly observations, with a view to their distribution among the more distinguished meteorologists and prominent meteorological institutions in different parts of the world.

THE verdict of the jury who considered the case of the Usworth Colliery explosion, whereby forty men and boys were killed early in the present year, is important as marking what appears to be the commencement of a new era in the history of these phenomena. It is probably the first expression of opinion from a public body of this class to the effect that coal-dust and a small percentage of fire-damp can play the part that has hitherto been usually ascribed to fire-damp alone. They found that the explosion was caused by a shot, the fire of which acted upon "the coal-dust and a small percentage of gas." The convenient and time-worn "outburst of gas" theory, which consigned the helpless miner to the vicissitudes of chance, and exonerated colliery owners and their agents from all responsibility, seems on the point of giving way before its rival the coal-dust theory, which poinis out an easy means of preventing great explosions of this kind. The latter theory has doubtless a hard battle still to fight against prejudice and ignorance, but it has all the advantages of youth and vigour on its side, and is supported by a number of facts which appear to be incontrovertible.

THE Russian Geographical Society has just issued a programme of climatological and phenological observations, which, it is to be hoped, will be adopted by numerous observers. The number of plants and animals enumerated is smaller than in most similar programmes, it being the aim of the Society to make the task of the observers as easy as possible. A new feature of this programme are observations on the condition of the snow covering the ground, the time of its appearance and thawing, the rise of water in the rivers at the melting of the snow, \&c.

M. FAYE has been continued on the roll of teachers of the Paris Polytechnic School, in spite of his having passed the time of incapacitation by old age. The exception has been grounded by the Minister of War on the plea of continued services rendered to science. A banquet has been given to the worthy astronomer by his admirers on this occasion. 